\title{
MENDISKUSIKAN HASIL PENGUJIAN HIPOTESIS PENELITIAN DALAM PENYUSUNAN DISERTASI : SEBUAH KAJIAN TEORITIS
}

\author{
I Gusti Ayu Agung Omika Dewi ${ }^{1 *}$ \\ ${ }^{1}$ Program Studi Akuntansi Universitas Pendidikan Nasional \\ *e-mail: omikadewi@undiknas.ac.id
}

DiPublikasi: 01/07/2021

https://doi.org/10.22225/kr.13.1.2021.31-39

\begin{abstract}
Discussing research results is an important stage in the dissertation preparation process. In general, in a dissertation there are several basic things that need to be considered in discussing research results, namely: summary of research results, interpretation of research results, placement of findings in the context of research, research implications, limitations of research, and suggestions for further research. One way to discuss research results is to look at whether or not the research hypothesis is supported. It is said that the ideal research is research whose hypothesis is supported or consistent with the theory and results of previous research. However, does the condition not supported by the research hypothesis indicate that a dissertation study has failed? This paper aims to discuss the process of discussing the results of dissertation research, especially on the results of hypothesis testing. After going through a theoretical study process, it can be seen that not supported by a hypothesis can actually enrich the research findings. If the hypothesis is not supported, of course, one must look for causes or reasons by discussing alternative explanations for the research findings and exploring what this means for philosophy, theory, and the world of practice in general.

Keywords: Research Hypothesis, Dissertation, Theoretical Study.
\end{abstract}

\begin{abstract}
Abstrak
Mendiskusikan hasil penelitian merupakan suatu tahapan penting dalam proses penyusunan disertasi. Secara umum, dalam disertasi terdapat beberapa hal mendasar yang perlu diperhatikan dalam mendiskusikan hasil penelitian, yaitu: rangkuman hasil penelitian, interpretasi hasil penelitian, penempatan temuan dalam konteks penelitian, implikasi penelitian, keterbatasan penelitian, serta saran untuk penelitian selanjutnya. Salah satu cara untuk mendiskusikan hasil penelitian adalah dengan melihat didukung ataupun tidak didukungnya hipotesis penelitian. Dikatakan bahwa penelitian yang ideal adalah penelitian yang hipotesisnya didukung atau konsisten dengan teori dan hasil-hasil penelitian terdahulu. Namun, apakah kondisi tidak didukungnya hipotesis penelitian mengindikasikan bahwa sebuah penelitian disertasi telah gagal? Paper ini bertujuan untuk membahas mengenai proses dalam mendiskusikan hasil penelitian disertasi, terutama pada hasil pengujian hipotesis. Setelah melalui proses kajian teoritis, dapat diketahui bahwa tidak didukungnya suatu hipotesis sebenarnya dapat memperkaya temuan penelitian. Jika hipotesis tidak didukung tentu saja harus dicari penyebab ataupun alasannya dengan mendiskusikan penjelasan alternatif bagi temuan penelitian dan mengeksplorasi apa artinya bagi filosofi teori, dan dunia praktik pada umumnya.
\end{abstract}

Kata Kunci : Hipotesis Penelitian, Disertasi, Kajian Teoritis.

\section{PENDAHULUAN}

Menurut beberapa literatur sampai saat ini belum ada konsensus yang universal tentang definisi mengenai disertasi (Cone dan Foster, 1993). Secara umum, disertasi dikenal sebagai sebuah karya tulis ilmiah yang merupakan tugas akhir dari seorang mahasiswa Program Doktor (S3) yang disusun, diujikan dan dipertahankan sebagai persyaratan untuk memperoleh Gelar Doktor (Dr). Sebuah disertasi disusun berdasarkan hasil penelitian yang tidak hanya menggambarkan proses menuangkan gagasan atau ide dalam tulisan, tetapi

juga menggambarkan seluruh aktivitas selama proses penelitian dilakukan. Seperti halnya skripsi atau tesis, disertasi juga merupakan suatu bentuk karya ilmiah namun metode yang digunakan lebih kompleks dan berbobot yang bertujuan untuk mengevaluasi kemampuan akademik mahasiswa dalam berpikir inovatif dan inventif dengan pendekatan inter, multi, maupun transdisipliner dalam mengidentifikasi, memecahkan masalah secara ilmiah serta memberikan unsur kebaruan ilmu (novelty) dalam penelitian yang dilakukan. 
Hal ini sejalan dengan yang disampaikan oleh Cone dan Foster (1993), bahwa salah satu tujuan utama penulisan disertasi adalah untuk mengungkapkan keterampilan peneliti atau mahasiswa dalam melakukan penelitian independen yang memberikan kontribusi orisinal untuk pengetahuan tentang topik yang dianggap penting.

Disertasi diharapkan memiliki nilai kemanfaataan yang tinggi untuk pengembangan suatu teori dan praktik serta dapat memuat dan menemukan alternatif pemecahan berbagai jenis rumusan masalah yang menjadi topik dalam penyusunan disertasi. Oleh sebab itu, sebuah topik disertasi tentu saja akan dipilih sesuai dengan bidang keilmuan yang ditekuni dan dikuasai seorang mahasiswa S3 sebagai peneliti. Lebih lanjut, disebutkan bahwa disertasi yang baik senantiasa disusun dengan memperhatikan kaidah ilmiah, yaitu rasional, faktual, sistematis, dan objektif dalam prosedur pengujian atau pembuktian dan penyimpulan. Salah satu fokus utama yang sering menjadi perhatian dalam mendiskusikan hasil penelitian disertasi adalah hasil pengujian hipotesis, agar peneliti bisa sampai kepada kesimpulan yang benar dan konsisten jika dikaitkan dengan research questions, dan tujuan penelitian. Hipotesis merupakan jawaban sementara terhadap permasalahan penelitian (Sugiyono, 2008). Penyusunan, pengujian, dan interpretasi hasil pengujian hipotesis ini sering dikatakan sebagai elemen kunci untuk menentukan keberhasilan ataupun kegagalan dari suatu penelitian disertasi.

\section{Fokus Permasalahan}

Banyak peneliti memiliki persepsi bahwa disertasi dikatakan baik dan berhasil apabila

\section{TINJAUAN PUSTAKA}

\section{Definisi, Perbedaan, Fungsi dan Asal-Usul Disertasi}

Cone dan Foster (1993) menyebutkan bahwa definisi disertasi menurut Webster (1950) adalah (1) sebuah wacana, perdebatan dan diskusi serta (2) bagaimana sebuah tulisan tentang suatu subjek yang tertulis, sebuah disquisition, atau sebuah esai dan risalah. Telah menjadi hal yang umum untuk membedakan antara disertasi dan tesis pada Universitas di Amerika Serikat, dengan mengacu pada proses penelitian yang telah dilakukan mahasiswa, dimana untuk gelar master hipotesis penelitian yang telah dirumuskan oleh peneliti, setelah dilakukan pengujian atau pembuktian secara statistik, menunjukkan hasil yang mendukung atau konsisten dengan teori atau hasil-hasil penelitian terdahulu yang dijadikan sebagai acuan. Namun, tidak jarang terjadi kondisi bahwa berdasarkan hasil pengujian secara statistik, hipotesis penelitian ternyata tidak didukung atau tidak konsisten dengan teori maupun hasil-hasil penelitian terdahulu. Padahal hipotesis penelitian tersebut telah dirumuskan sejalan dengan research questions, dan tujuan penelitian.

Apakah kondisi bahwa tidak didukungnya hipotesis penelitian berdasarkan hasil pengujian secara statistik dapat dikatakan telah terjadi kegagalan dalam penyusunan disertasi? Paper ini secara umum berupaya untuk membahas mengenai proses mendiskusikan hasil penelitian yang meliputi: rangkuman hasil penelitian, interpretasi hasil penelitian, penempatan temuan dalam konteks penelitian, implikasi penelitian, keterbatasan penelitian, serta saran untuk penelitian selanjutnya. Paper ini terutama berfokus pada penjelasan mengenai permasalahan tentang didukung ataupun tidak didukungnya hipotesis penelitian berdasarkan hasil pengujian secara statistik dengan mengacu pada teori dan hasil-hasil penelitian terdahulu. Paper ini juga berupaya untuk mendiskusikan penjelasan alternatif terkait teori dan praktik untuk hipotesis penelitian disertasi yang tidak didukung untuk kemudian dieksplorasi alasan ataupun penyebab mengenai tidak didukungnya hipotesis penelitian tersebut.

menggunakan istilah disertasi. Lebih lanjut Cone dan Foster (1993) menyebutkan bahwa Katalog Universitas Yale (1975: 182) menegaskan bahwa disertasi mengungkapkan pencapaian mahasiswa dalam penguasaan teknis terhadap bidang spesialisasinya, mampu melakukan pekerjaan ilmiah mandiri, dan mampu merumuskan kesimpulan yang dalam beberapa hal akan mengubah apa yang telah ada dan dikenal sebelumnya. Dengan demikian, disertasi lebih kepada bagaimana pengujian terhadap kompetensi mahasiswa untuk belajar secara mandiri sebagai peneliti yang menghasilkan sebuah produk jadi 
berupa sebuah kontradiksi baru dan signifikan. Evolusi atau asal-usul disertasi sungguh bervariasi dari berbagai negara, tetapi dilihat dari proses penyusunannya secara umum tetap cukup konsisten pada negara satu dan lainnya, dimana sebagian besar mahasiswa Program Doktor tersebut memilih untuk melakukan penelitian empiris guna memenuhi persyaratan doktoral mereka.

\section{Topografi dan Motivasi Penyusunan Disertasi}

Topografi sebuah disertasi sangat erat kaitannya dengan beberapa pertanyaan sebagai seorang mahasiswa doktoral. Mungkin kita bertanya pada diri sendiri, sejumlah pertanyaan tentang topik disertasi apa yang seharusnya diambil. Berapa lama seharusnya disertasi dikerjakan? Format apa yang seharusnya kita ikuti? Apakah ada persyaratan dan gaya penulisan yang harus diikuti, dan sebagainya. Adapun panjang pendeknya, banyaknya variabilitas dalam sebuah disertasi tergantung pada data yang ingin kita peroleh. Cone dan Foster (1993) menyebutkan bahwa meskipun tidak terdapat data obyektif pada disertasi, tetap dapat diketahui sesuatu tentang seberapa perlu kita mencari data dalam sebuah disertasi. Kita harus belajar untuk menikmati proses dalam melakukan sebuah penelitian disertasi yang bagi banyak orang, merupakan pengalaman belajar yang paling utama.

Motivasi penyusunan disertasi adalah terkait dengan alasan yang masuk akal mengapa kita menulis sebuah disertasi, dimana salah satunya adalah untuk mendapatkan gelar tertentu. Saat kita telah bekerja keras menyelesaikan tugas pokok sebagai seorang mahasiswa, sangatlah disayangkan jika kita tidak menyelesaikan langkah terakhir menuju gelar yang diinginkan. Alasan lainnya tentu saja mengenai alasan ekonomis, disertasi bisa menjadi tiket ke penghasilan yang lebih tinggi, akademis atau terapan, penunjang pekerjaan, dan awal untuk sebuah karir profesional. Alasan lainnya adalah intelektual, dimana penelitian menawarkan banyak tantangan dan kesempatan untuk berpikir tentang cara untuk memecahkan masalah konseptual, metodologis, dan praktis. Melakukan penelitian juga merupakan salah satu cara untuk mengetahui beberapa psikologi atau fenomena ilmu perilaku lainnya yang menambah wawasan berpikir. Menyelesaikan disertasi pada akhirnya akan dapat memberikan kepuasan tersendiri karena telah berhasil menguasai tugas yang kompleks dan menantang.

\section{Hipotesis dan Strategi Penelitian Disertasi}

Hipotesis adalah pernyataan resmi yang menyajikan hubungan yang diharapkan antara variabel independen dan dependen (Creswell, 1994). Dalam penelitian kuantitatif, peneliti biasanya menyajikan rumusan masalah dan hipotesis penelitian serta sasaran atau tujuan penelitian. Rumusan masalah kuantitatif biasanya berupa pertanyaan-pertanyaan tentang hubungan antara variabel-variabel yang akan dianalisis oleh peneliti. Sementara itu, hipotesis kuantitatif merupakan prediksi-prediksi yang dibuat peneliti tentang hubungan antar variabel yang diharapkan (Creswell dan Creswell, 2018). Hipotesis biasanya berupa perkiraan numerik atas populasi yang dinilai berdasarkan data sampel penelitian. Menguji hipotesis berarti menerapkan prosedur-prosedur statistik dimana di dalamnya peneliti mendeskripsikan dugaan-dugaannya terhadap populasi tertentu berdasarkan sampel penelitian (Creswell, 2016).

Penelitian adalah proses mengumpulkan, menganalisis, dan menafsirkan data untuk memahami suatu fenomena (Leedy dan Ormrod, 2001). Menurut TerreBlanche dan Durrheim (1999), proses penelitian memiliki tiga dimensi utama yaitu ontologi, epistemologi dan metodologi (Antwi dan Hamza, 2015). Proses penelitian dilakukan secara sistematis, yaitu mendefinisikan tujuan, mengelola data, dan mengkomunikasikan temuan yang terjadi dalam kerangka kerja yang telah ditetapkan dan sesuai dengan pedoman yang ada (Williams, 2007). Guba dan Lincoln (1994) menyarankan bahwa penyelidikan penelitian harus didasarkan pada konsep ontologi (yaitu, cara penyidik mendefinisikan kebenaran dan realitas), epistemologi (yaitu, proses dimana peneliti mengetahui kebenaran dan kenyataan) dan metodologi (yaitu, metode yang digunakan dalam melakukan investigasi).

Penelitian kuantitatif dimulai dengan pernyataan masalah dan melibatkan pembentukan hipotesis, tinjauan pustaka, dan analisis data kuantitatif, dimana temuan pada penelitian kuantitatif ini dapat bersifat prediktif, penjelasan, dan konfirmasi. Creswell (2003) menyatakan, penelitian kuantitatif menggunakan strategi penyelidikan seperti eksperimen dan survei, dan mengumpulkan data pada instrumen yang telah 
ditentukan sebelumnya yang menghasilkan data statistik. Strategi penelitian menurut Saunders et.al. (2009) adalah rencana umum bagaimana peneliti akan menjawab pertanyaan penelitian. Strategi penelitian disertasi merupakan orientasi umum atas pelaksanaan penelitian yang memberikan arahan mengenai keseluruhan penelitian termasuk proses bagaimana penelitian dilakukan (Bryman, 2008; Remenyi et.al. 2003; Hartono, 2018).

\section{Merangkum dan Menginterpretasikan Hasil Penelitian Disertasi}

Sebagian besar diskusi hasil penelitian dimulai dengan sebuah ringkasan integratif dari hasil penelitian yang dideskripsikan sejelas mungkin, dengan menggunakan jargon statistik seminimal mungkin. Salah satu cara untuk mengatur rangkuman penelitian adalah dengan melihat hasil penelitian tersebut apakah mendukung atau tidak mendukung hipotesis penelitian atau pertanyaan penelitian. Rangkuman ini secara logis dapat mengarahkan ke diskusi tentang berbagai alasan mengenai ditemukan ataupun tidak ditemukannya apa yang sebenarnya ingin ditemukan. Diskusikanlah hasil pengujian hipotesis dalam urutan yang semula dicantumkan di subbagian pertanyaan penelitian dan tinjauan pustaka, kemudian nyatakan kembali secara singkat setiap hipotesis sehingga pembaca tidak perlu lagi kembali ke bagian sebelumnya. Diskusi ini juga harus mencerminkan urutan dari hasil temuan penelitian. Cara alternatif untuk meringkas hasil temuan penelitian adalah dengan menyajikan temuan utama secara bersama-sama (Cone dan Foster, 1993).

Rangkuman hasil penelitian merupakan salah satu bagian dari interpretasi hasil penelitian. Interpretasi hasil penelitian dilakukan dengan melihat hasil dari pengujian hipotesis penelitian. Peneliti akan segera dapat langsung melakukan interpretasi terhadap temuan penelitian, jika hasil pengujian hipotesis penelitian didukung secara statistik atau konsisten dengan research question dan tujuan penelitian, karena peneliti telah memikirkan interpretasi tersebut ketika peneliti merancang penelitian. Jika peneliti kurang beruntung, dimana hasil pengujian hipotesis penelitian tidak didukung secara statistik atau tidak konsisten dengan research question dan tujuan penelitian, peneliti dapat melanjutkan dengan mendiskusikan penjelasan alternatif untuk temuan penelitian dan mengeksplorasi apa artinya bagi teori, praktik, dan dunia pada umumnya. Mayoritas peneliti, bagaimanapun juga tidak akan selalu mendapatkan hasil temuan penelitian sesuai dengan apa yang telah diprediksi sebelumnya.

\section{Menempatkan Temuan dalam Konteks Penelitian Disertasi}

Saat peneliti merangkum dan menjelaskan sebuah hasil penelitian disertasi perlu dipertimbangkan bahwa bisa saja hasil penelitian tidak sesuai dengan literatur yang telah diulas sebelumnya. Banyak topik yang memberikan manfaat untuk diskusi ini. Pertama, pertimbangkan bahwa temuan penelitian sesuai dengan ulasan kajian literatur yang telah disusun sebelumnya, dengan cara membandingkan penelitian saat ini dengan penelitian terdahulu dalam hal karakteristik populasi, alat pengukuran, variabel independen (dan verifikasinya), desain penelitian, serta prosedur. Kedua, pikirkan bahwa hasil penelitian sesuai atau bertentangan dengan temuan sebelumnya. Jika temuan penelitian menujukkan hasil yang sama dengan penelitian terdahulu, perbedaan antara metode penelitian yang digunakan mungkin menunjukkan cara bagaimana penelitian yang dilakukan dapat memperluas temuan penelitian sebelumnya.

Hasil penelitian mungkin juga menjelaskan kontradiksi dalam literatur. Jika demikian, peneliti dapat menjelaskan temuan yang kontradiktif saat mereka memeriksa perbedaan baru terkait parameter populasi, domain pengukuran, dan variabel independen. Jika peneliti membuat perbedaan semacam ini, temuan penelitian akan dapat membantu orang lain memahami literatur yang ada dengan lebih baik. Jika peneliti gagal menemukan apa yang ditemukan orang lain, pertimbangkan alasannya. Hargai perbedaan antara penelitian yang dilakukan dengan penelitian yang dilakukan peneliti lain. Pertimbangkan penjelasan metodologis bahwa ukuran, prosedur, atau sampel yang berbeda dapat menjelaskan adanya perbedaan tersebut. Selain itu, perlu diskusikan mengenai kegagalan dalam mereplikasi hasil penelitian terdahulu tentang batasan terhadap generalisasi temuan penelitian tersebut (Cone dan Foster, 1993).

\section{Mempertimbangkan Implikasi dari Temuan Penelitian Disertasi}

Ada beberapa hal yang perlu dipertimbangkan terkait implikasi dari hasil 
penelitian, yakni koneksinya terhadap teori, penelitian, dan praktik. Berkenaan dengan teori, pertama-tama pikirkan tentang model teoritis yang berlaku di bidang penelitian. Sebuah temuan penelitian tidaklah membuktikan atau menyangkal teori, melainkan hanya mendukung atau gagal mendukung teori. Meskipun alangkah baiknya jika temuan penelitian bisa konsisten dengan salah satu teori, serta dapat dijelaskan dengan baik oleh lebih dari satu teori. Berkenaan dengan metodologi penelitian, ingatlah, pemahaman tentang suatu fenomena akan semakin maju apabila ada perbedaan penting yang dibuat. Perlu diperhatikan bahwa penelitian akan menyiratkan adanya perbedaan baru atau faktor apa pun yang penting untuk dikontrol dalam penyelidikan lebih lanjut.

Secara umum, penelitian sering berkembang dari umum ke spesifik, dan dari desain lemah menjadi kuat. Jadi, jika peneliti menggunakan desain longitudinal dan gagal menemukan apa yang ditemukan oleh studi crosssectional, peneliti dapat menggunakan hasil penelitian untuk mendiskusikan penggunaan desain yang lebih kuat secara berkelanjutan yang memberikan hasil yang lebih meyakinkan. Beberapa penelitian tentunya dapat memiliki implikasi yang lebih banyak sebagai acuan untuk praktik daripada penelitian yang lain. Penelitian yang melibatkan populasi bisnis, misalnya, cenderung memiliki banyak aplikasi praktis; investigasi sains dasar dalam psikologi fisiologis mungkin tidak ada. Jika temuan penelitian memiliki implikasi potensial untuk pekerjaan terapan, pastikan untuk mempertimbangkan batasannya juga (Cone dan Foster, 1993).

\section{Menjelaskan Keterbatasan Penelitian Disertasi}

Bagian diskusi tentu saja merupakan tempat untuk membanggakan (secara halus, tentu saja) tentang kualitas penelitian dan pentingnya temuan penelitian tersebut. Namun, kebanggaan ini harus diimbangi dengan pengakuan bahwa tidak ada penelitian yang sempurna yang memungkinkan peneliti untuk menunjukkan keterbatasan penelitian. Batasan penelaahan peneliti umumnya berasal dari dua sumber: (a) keputusan yang dibuat tentang bagaimana melakukan penelaahan dan (b) masalah yang muncul saat melaksanakannya. Keputusan tentang kriteria untuk memasukkan subjek, prosedur, ukuran, dan desain semuanya dapat membawa keterbatasan dan juga kekuatan. Di bagian diskusi ini, peneliti mungkin telah mengantisipasi beberapa potensi masalah dan mengambil langkah untuk menghindarinya. Peneliti perlu untuk menunjukkan (dengan rendah hati, untuk memastikan) bagaimana menangani potensi keterbatasan tersebut (Cone dan Foster, 1993).

\section{Komentar Tentang Arah Penelitian Disertasi Mendatang}

Biasanya, bagian diskusi penelitian akan diakhiri dengan menunjukkan arah yang perlu dilakukan peneliti di masa mendatang. Peneliti disini dapat memberi tahu peneliti lain mengenai pertanyaan dan masalah apa yang harus mereka teliti, berdasarkan temuan penelitian. Para peneliti sering mengatakan bahwa setiap penelitian menimbulkan lebih banyak pertanyaan daripada jawabannya. Dalam menulis bagian sebelumnya, peneliti harus memikirkan banyak pertanyaan yang memerlukan penelitian di masa mendatang.

Pertanyaan-pertanyan yang memerlukan jawaban pada penelitian mendatang hendaknya dikumpulkan dan diuraikan di bagian diskusi penelitian. Kebanyakan peneliti berdiskusi dan berpikir dengan mudah untuk memperluas penelitian ke populasi lain. Peneliti dapat melampaui ini dengan memikirkan beberapa pertanyaan tambahan. Idealnya, teori yang mendasari sebuah penelitian akan memicu pertanyaan-pertanyaan berikut : (1) variabel independen tambahan apa yang perlu dipelajari lebih lanjut? (2) tingkat tambahan apa dari variabel independen yang ada yang harus dipelajari oleh peneliti? (3) Variabel dependen penting apa yang harus diperiksa, dan apa cara terbaik untuk menilai ini? (4) Perbaikan desain apa yang dibutuhkan? (5) Inovasi metodologis apa yang harus dilakukan peneliti dalam penelitian di masa depan? Selain itu, pikirkan tentang perbedaan baru apa yang mungkin dibuat dalam karakteristik populasi, variabel independen, dan variabel dependen (Cone dan Foster,

\section{HASIL DAN PEMBAHASAN}

Ketika mendiskusikan hasil penelitian dalam disertasi, perlu diperhatikan beberapa hal 
penting yakni : berpikir kritis dalam menyimpulkan hasil penelitian, hindari kesalahan yang sifatnya umum, serta memilih strategi yang sesuai dalam mendiskusikan hasil penelitian. Selain itu, ada beberapa pertanyaan penting yang perlu menjadi fokus perhatian dalam mendiskusikan hasil penelitian disertasi yang meliputi : (1) Apakah yang dimaksud dengan hasil penelitian? (2) Apakah hasil penelitian anda memberikan informasi tentang hubungan antara variabel independen dan variabel dependen? (3) Apakah hubungan tersebut berlaku untuk beberapa atau hanya variabel dependen terpilih? (4) Apakah ada kontroversi atau mediator yang dapat mempertanggungjawabkan temuan penelitian tersebut?

Salah satu fokus utama dalam mendiskusikan hasil penelitian disertasi seperti yang sudah disampaikan sebelumnya adalah pada hasil pengujian hipotesis penelitian. Beberapa dari peneliti mungkin akan merasa senang, karena penelitian yang dilakukan akan menjadi persis seperti yang diprediksi dengan didukungnya hipotesis penelitian secara statistik tetapi apabila hipotesis tersebut tidak didukung secara statistik sering membuat peneliti merasa tidak senang. Padahal tidak didukungnya hipotesis tersebut sebenarnya dapat memperkaya temuan penelitian. Ilmu pengetahuan akuntansi akan semakin maju melalui adanya akumulasi informasi. Beberapa di antaranya melibatkan prediksi yang gagal atau tidak didukungnya suatu hipotesis penelitian. Prediksi yang gagal atau hipotesis yang tidak didukung bisa sama pentingnya dengan prediksi atau hipotesis yang didukung dalam studi yang dirancang dengan baik dengan ukuran sampel yang memadai dan ukuran yang andal dan valid.

Adanya kasus bahwa hipotesis penelitian tidak didukung secara statistik atau prediksi peneliti yang dianggap gagal mungkin menunjukkan bahwa kerangka kerja yang mengarah pada perumusan dan pengujian hipotesis penelitian mungkin perlu direvisi. Bagaimanapun, juga perlu diingat bahwa tidak adanya temuan yang signifikan tidak mengkonfirmasi hipotesis nol, dan mempertimbangkan berbagai penjelasan yang masuk akal. Dengan tidak adanya temuan signifikan di bidang lain, peneliti selalu bisa menghubungkan variabel demografis dengan variabel dependen, dan di antara variabel dependen satu sama lain. Hal ini akan memberikan informasi tambahan untuk dibahas jika tidak ada temuan yang lebih substantif (Cone dan Foster, 1993).

Menghadapi kondisi bahwa tidak semua hasil penelitian disertasi mendapatkan temuan sesuai dengan yang diperkirakan, peneliti dikatakan harus merasa bersyukur, karena dapat membahas banyak hal dalam mendiskusikan hasil penelitian. Dalam kasus ini, harus dipertimbangkan variabel mana yang menunjukkan hubungan yang diprediksi dan mana yang tidak. Kemudian pertimbangkan mengapa ini bisa terjadi. Apakah variabel signifikan memiliki kesamaan? Dimana letak kesamaannya? Mengapa variabel yang tidak signifikan berubah seperti itu? Dengan kata lain, bandingkan dan kontraskan yang signifikan dengan temuan yang tidak signifikan, periksa mengapa perbedaan itu ada dan apa yang mungkin dikatakan perbedaan ini tentang fenomena yang dipelajari. Pertimbangkan juga mengapa ukuran yang digunakan tidak semuanya disetujui berdasarkan beberapa pertimbangan berikut: (a) masalah instrumentasi; (b) dokumentasi atau manipulasi variabel independen yang tidak memadai; (c) ukuran sampel yang tidak memadai; (d) aspek prosedural khusus dari penelitian yang mungkin telah menekan efek variabel independen; dan (e) hubungan yang benar antara variabel independen dan dependen selain yang diprediksi.

Kondisi tidak didukungnya hipotesis penelitian dapat menunjukkan adanya perbedaan baru yang dapat dilakukan peneliti untuk memperkaya literatur di masa mendatang. Jika peneliti menemui kegagalan dalam menemukan apa yang ditemukan peneliti terdahulu, kegagalan tersebut bukanlah merupakan kegagalan dalam penelitian disertasi yang dilakukan. Namun, dapat dikatakan bahwa peneliti mungkin telah menemukan sesuatu yang penting atau suatu kebaruan mengenai fenomena yang diperiksa. Perlu diingat bahwa, penelitian disertasi seharusnya dapat memberikan kontribusi baru bagi ilmu pengetahuan serta bagi literatur akuntansi yang ada. Oleh sebab itu, perlu ditunjukkan bahwa peneliti telah melakukan hal yang berbeda jika dibandingkan dengan penelitian terdahulu. Dalam hal ini perlu diperlihatkan mengenai apa yang telah dilakukan peneliti yang tidak dilakukan oleh peneliti sebelumnya, bagaimana penelitian ini dapat meningkatkan investigasi pada penelitian sebelumnya, serta kaitan antara hasil peningkatan investigasi ini dengan temuan penelitian. Temuan penelitian mungkin akan membawa peneliti ke 
masalah penting lainnya, yakni peran spekulasi di bagian diskusi, dimana perlu diperhatikan bahwa logika peneliti dapat dibenarkan berdasarkan temuan penelitian sendiri atau orang lain. Kuncinya adalah secara eksplisit terletak pada spekulasi dan membahas bukti yang mendukung dan menentangnya.

Masalah tak terhindarkan yang membatasi temuan penelitian seringkali muncul saat melakukan penelitian, yang meliputi : sampel penelitian mungkin lebih kecil dari yang direncanakan, sehingga membatasi kekuatan statistik; tingkat persetujuan mungkin rendah; subjek mungkin telah keluar dari penelitian. Terkait dengan permasalahan tersebut, perlu dipikirkan tentang kemungkinan keterbatasan penelitian di empat bidang utama (Cone dan Foster, 1993), yaitu

1. Desain investigasi yang melibatkan validitas internal, terkait keterbatasan apakah peneliti dapat mengatribusikan status kausal ke variabel independen, variabel pengganggu potensial, dan sebagainya (dapat dilihat pada buku klasik Campbell dan Stanley (1963) dan Cook and Campbell (1979).

2. Desain investigasi yang melibatkan validitas eksternal, terkait generalisasi temuan penelitian ke populasi, tugas atau situasi lain, pengaturan noneksperimental, dan sebagainya

3. Pengukuran yang melibatkan reliabilitas, validitas, dan ruang lingkup pengukuran penelitian, serta apakah rangkaian respons atau masalah pengukuran lain mungkin telah berkontribusi pada temuan penelitian

4. Analisis statistik yang dipilih, meliputi: data yang memenuhi asumsi statistik; tingkat konservatisme dan liberalisme dari statistik dalam penelitian; ukuran sampel yang membatasi kekuatan statistik untuk mendeteksi apa pun kecuali efek terkuat; mengontrol kesalahan dengan membatasi jumlah uji statistik yang digunakan sebelumnya; serta penggunaan prosedur statistik baru yang tidak memiliki penjabaran penuh atas asumsi dan masalahnya.

Sebuah penelitian disertasi mungkin saja tidak memiliki keterbatasan di semua bidang yang telah dijabarkan di atas, tetapi masing-masing harus dipertimbangkan saat peneliti menilai kekuatan dan kelemahan penelitian. Ada pandangan bahwa peneliti mungkin percaya mengenai banyaknya keterbatasan penelitian membuat temuan penelitian tidak berharga. Pandangan tersebut bisa saja merupakan hal yang keliru. Saat peneliti menyusun disertasi, perlu diingat bahwa tidak ada penelitian yang sempurna. Hasil dari setiap penelitian harus dipertimbangkan keterbatasannya, mengingat kesimpulan akhir penelitian dicapai berdasarkan sekumpulan bukti, bukan investigasi tunggal. Setiap keterbatasan penelitian tentu saja memiliki keunggulan tersendiri, misalnya sebuah penelitian eksperimen laboratorium yang ketat akan mengorbankan kemampuan generalisasi (validitas eksternal), sedangkan penelitian eksperimen semu akan mendapatkan kemampuan generalisasi dengan mengorbankan validitas internal.

Saat peneliti mempertimbangkan suatu kesimpulan penelitian, dapat diistilahkan bahwa peneliti dikatakan berperan sebagai kritikus yang menanggapi diskusi penelitian. Dalam hal ini perlu dilakukan antisipasi terhadap adanya kritik dan perlu dimasukkan sanggahan peneliti ke dalam diskusi penelitian. Pemikiran kritis terkait diskusi hasil penelitian ini dapat mengisi halaman disertasi dan mendemonstrasikan kecerdasan intelektual peneliti yang melibatkan logika peneliti itu sendiri. Perlu diingat juga bahwa penting untuk menunjukkan kepada pembaca langkah-langkah dalam menuangkan logika peneliti dalam penyusunan disertasi. Jangan berasumsi bahwa hanya dengan mempresentasikan temuan penelitian akan membuat kesimpulan penelitian menjadi jelas. Jika peneliti membuat asumsi dalam menarik kesimpulan penelitian, maka perlu ditunjukkan kepada pembaca bahwa kesimpulan penelitian tersebut berasal dari serangkaian pemikiran. Kesimpulan yang dibuat oleh peneliti mungkin tampak sederhana setelah dituangkan dalam tulisan disertasi, namun perlu diingat bahwa betapa banyak pemikiran yang diperlukan oleh peneliti untuk mencari tahu mengenai hasil dari suatu pengujian hipotesis. Jadi, dalam hal ini perlu diasumsikan bahwa pihak pembaca perlu dibimbing melalui proses yang sama agar bisa sampai kepada kesimpulan penelitian yang tepat dan sesuai dengan keseluruhan isi penelitian disertasi.

Serangkaian permasalahan umum seringkali menjadi ciri bagian pembahasan dari 
sebuah penelitian disertasi. Oleh sebab itu, dalam melakukan pembahasan disertasi, perlu dihindari beberapa kesalahan berikut: (1) hindari melakukan pembahasan temuan penelitian disertasi yang hampir signifikan atau tidak signifikan ke arah yang benar seolah-olah itu signifikan; (2) hindari penggunaan bahasa kausal untuk membahas temuan korelasional; (3) hindari menyamakan signifikansi statistik dengan ukuran efek (effect size); (4) hindari penggunaan bahasa yang mengasumsikan bahwa laporan dari peristiwa berarti peristiwa yang sebenarnya terjadi; (5) hindari penyajian analisis baru untuk pertama kalinya di bagian diskusi atau membahas hasil yang tidak dilaporkan di bagian hasil; (6) hindari pengulangan kembali bagian hasil. Seperti yang telah ditekankan berulang kali, penelitian disertasi yang dilakukan adalah lebih dari sekadar ringkasan untuk menafsirkan, mensintesis, menganalisis, dan mengkritik temuan penelitian. Penting bagi peneliti untuk menunjukkan logika penelitian kepada pembaca, dimana saat peneliti melakukannya, perlu untuk mengakui adanya spekulasi saat peneliti terlibat di dalamnya (Cone dan Foster, 1993).

Ketika mendiskusikan mengenai keterbatasan penelitian sangatlah erat kaitannya dengan saran yang akan diberikan bagi penelitian selanjutnya. Dalam hal ini perlu diperhatikan adanya perbedaan antara penelitian disertasi yang dilakukan dengan penelitian terdahulu yang digunakan sebagai acuan, sebagai saran perbandingan yang dapat dibuat atau diberikan bagi penelitian selanjutnya. Satu cara yang dapat dilakukan untuk memikirkan arah masa depan penelitian selanjutnya adalah dengan bertanya pada diri sendiri selaku peneliti kira-kira studi lanjutan apa yang akan dilakukan berdasarkan hasil penelitian, dengan mengacu pada pertanyaanpertanyaan berikut: (1) Pertanyaan apa yang ditanyakan oleh temuan penelitian? (2) Apa lagi yang perlu diketahui untuk memahami sepenuhnya

\section{KESIMPULAN DAN SARAN}

\section{Kesimpulan}

Disertasi dikenal sebagai sebuah karya tulis ilmiah yang merupakan tugas akhir dari seorang mahasiswa Program Doktor (S3) yang disusun, diujikan dan dipertahankan sebagai persyaratan untuk memperoleh Gelar Doktor (Dr). Salah satu fokus utama yang sering menjadi perhatian dalam mendiskusikan hasil penelitian disertasi adalah masalah yang ingin ditangani dalam penelitian? (3) Apa yang akan dilakukan dengan sumber daya tak terbatas? Dapat dikatakan bahwa dalam memberikan saran mengenai arah penelitian selanjutnya di masa depan dapat dikatakan sebagai tempat bagi peneliti untuk berimajinasi. Tentu saja, harus dipastikan bahwa imajinasi peneliti yang dituangkan dalam saran bagi peneliti selanjutnya tersebut didasarkan pada kenyataan bahwa peneliti dapat membenarkan bahwa informasi yang dikumpulkan selama proses penelitian adalah penting untuk penelitian masa depan terutama dalam konteks teori maupun praktik bagi penelitian selanjutnya.

Meskipun ada banyak cara untuk mengatur bagian diskusi, menurut Cone dan Foster (1993), terdapat dua struktur umum yang bekerja dengan baik, yaitu : (1) peneliti dapat maju dari rangkuman penelitian ke interpretasi dan implikasi, ke integrasi dengan literatur yang ada, batasan, dan arah masa depan; (2) peneliti melibatkan pengorganisasian diskusi seputar temuan utama, dan mengintegrasikan implikasi, temuan penelitian terdahulu, dan batasan spesifik ke dalam diskusi penelitian tentang setiap temuan. Lebih lanjut Cone dan Foster (1993) juga menyarankan untuk mengakhiri bagian diskusi penelitian dengan paragraf penutup yang menyatukan diskusi dan menyoroti beberapa poin utama penelitian, tanpa membuat ringkasan. Perlu dicatat bahwa, sebuah diskusi penelitian disertasi biasanya dimulai dengan suatu pernyataan umum dan diakhiri dengan suatu pernyataan yang lebih khusus. Perlu juga diperhatikan bahwa penting bagi peneliti untuk memahami secara penuh tentang area penelitian yang diselidiki, sehingga peneliti bisa memberikan gambaran kepada pembaca mengenai pemahaman proses atau individu yang sedang diselidiki akan dapat memperkaya dimensi teori atau praktik dalam konteks penelitian yang dilakukan.

hasil pengujian hipotesis, agar peneliti bisa sampai kepada kesimpulan yang benar dan konsisten jika dikaitkan dengan research questions, dan tujuan penelitian. Paper ini telah menguraikan secara umum mengenai proses mendiskusikan hasil penelitian yang meliputi: rangkuman hasil penelitian, interpretasi hasil penelitian, penempatan temuan dalam konteks penelitian, implikasi 
penelitian, keterbatasan penelitian, serta saran untuk penelitian selanjutnya. Sesuai fokus permasalahan yang telah diuraikan, paper ini berupaya memberikan penjelasan khususnya mengenai didukung ataupun tidak didukungnya hipotesis penelitian berdasarkan hasil pengujian secara statistik dengan mengacu pada teori dan hasil-hasil penelitian terdahulu. Berdasarkan proses kajian teoritis dapat disimpulkan bahwa tidak didukungnya hipotesis penelitian bukan berarti bahwa penelitian disertasi telah gagal, namun sebenarnya dapat memperkaya temuan penelitian. Prediksi yang gagal atau hipotesis yang tidak didukung bisa sama pentingnya dengan prediksi atau hipotesis yang didukung sebagai upaya membuat ilmu pengetahuan akuntansi akan semakin maju melalui adanya akumulasi informasi yang berbeda.

\section{Saran}

\section{DAFTAR PUSTAKA}

Antwi, Stephen Kwadwo and Kasim Hamza. 2015. Qualitative and Quantitative Research Paradigm in Business Research : A Philosophical Reflection. European Journal of Business and Management, Vol. 7, No.3, pp : 217-226

Bryman, A. 2008. Social Research Methods. $4^{\text {th }}$ Edition, Oxford, Oxford University Press.

Campbell. D.T., dan Stanley, J.C. 1963. Experimental and Quasi-Experimental Design for Research. Chicago : Rand Mcnally.

Cone, John D. dan Sharon L Foster. 1997. Dissertations and Theses From Start to Finish : Psychology and Related Fields. American Psychological Association. Washington DC.

Cook, T.D. dan Campbell. D.T. 1979. Quasi-Experimentation : Design and Analysis Issues for Field Settings. Boston : Houghton Mifflin.

Creswell, J. W. (1994). Research design: Qualitative and quantitative approaches. Thousand Oaks, CA: SAGE Publications.

Creswell, J. (2003). Research design: Qualitative, quantitative and mixed methods approaches (2nd ed.). Thousand Oaks, CA: SAGE Publications.

Creswell, John W. 2016. Research Design: Pendekatan Metode Kualitatif, Kuantitaif, dan Campuran. Pustaka Pelajar: Yogyakarta.

Creswell, John W. and J. David Creswell. 2018. Research
Mayoritas peneliti, bagaimanapun juga tidak akan selalu mendapatkan hasil temuan penelitian sesuai dengan apa yang telah diprediksi sebelumnya. Berdasarkan keseluruhan pemaparan tentang mendiskusikan hasil pengujian hipotesis penelitian dalam penyusunan disertasi dapat disarankan bahwa ketika peneliti menemukan kondisi bahwa hipotesis penelitiannya didukung ataupun tidak didukung, maka peneliti hendaknya berupaya untuk mencari penjelasan terhadap kondisi tersebut. Hipotesis penelitian yang didukung ataupun tidak didukung sama-sama memerlukan adanya justifikasi. Hanya saja bagi hipotesis penelitian yang tidak didukung justifikasi yang ditampilkan akan lebih kompleks karena memerlukan penjelasan yang lebih detail dan terperinci, terutama mengenai penjelasan alternatif yang mengeksplorasi arti temuan penelitian bagi filosofi teori, dan dunia praktik pada umumnya.

Design Qualitative, Quantitative, and Mixed Method Approaches. USA : Sage Publications, Inc.

Guba, E. \& Lincoln, Y. (1994), "Competing paradigms in qualitative research". In N. Denzin and Y. Lincoln (eds.), Handbook of Qualitative Research (pp. 105117). California: Sage.

Hartono, Jogiyanto dan Mahfud Sholihin. 2018. Strategi Penelitian Bisnis. Andi : Yogyakarta.

Leedy, P. \& Ormrod, J. (2001). Practical research: Planning and design (7th ed.). Upper Saddle River, NJ: Merrill Prentice Hall. Thousand Oaks: SAGE Publications.

Remenyi, D. Williams, B., Money, A. dan Swartz, E. 2003. Doing Research in Business and Management : An Introduction to Process and Method. London, SAGE Publications.

Saunders, M., Lewis,P. dan Thornhill, A. 2009. Research Methods for Business Student. $5^{\text {th }}$ ed. Harlow, Pearson Education.

Sugiyono. 2008. Metode Penelitian Kuantitatif Kualitatif dan R\&D. Bandung: Penerbit Alfabeta.

Webster's New International Dictionary $2^{\text {nd }}$ Ed. 1950. Springfield, MA: G\&C Merriam.

Williams, Carrie, 2007. Research Methods. Journal of Business \& Economic Research. Volume 5, Number 3.

Yale University. 1975. Yale University Catalog. New Haven, CT : Author. 